\title{
THE INCIDENCE OF JACKAL BITES AND INJURIES IN THE ZAGREB ANTI RABIES CLINIC DURING THE 1995-2014 PERIOD
}

\author{
Radovan Vodopija ${ }^{1}$, Aleksandar Racz ${ }^{2}$ and Đana Pahor ${ }^{3}$ \\ ${ }^{1}$ Andrija Štampar Teaching Institute of Public Health; ${ }^{2}$ University of Applied Health Sciences, Zagreb; ${ }^{3}$ Teaching \\ Institute of Public Health of Primorje-Gorski Kotar County, Rijeka, Croatia
}

\begin{abstract}
SUMMARY - Rabies is a zoonotic disease (a disease transmitted to humans from animals) that is caused by a virus. The disease affects domestic and wild animals, and is spread to people through close contact with infectious material, usually saliva, via bites or scratches. Rabies is present on all continents with the exception of Antarctica, but more than 95\% of human deaths occur in Asia and Africa. Once the symptoms of the disease have developed, rabies is nearly always fatal. People are usually infected following deep bite or scratch by an infected animal. Dogs are the main host and transmitter of rabies. They are the source of infection in all of the estimated 55000 human rabies deaths annually in Asia and Africa. Bats are the source of most human rabies deaths in the Americas. Bat rabies has also recently emerged as a public health threat in Australia and Western Europe. Human deaths following exposure to foxes, raccoons, skunks, jackals, mongooses and other wild carnivore host species are very rare. In the Zagreb Anti Rabies Clinic, from 1995 to 2014, there were 18,094 patients bitten by various animals, but only 2 cases were caused by jackals. One was imported (from France), and the other was from Croatia. The incidence of jackal injuries during the observed period was extremely low, accounting for $0.011 \%$ of all animals. When the imported case is excluded, the incidence was $0.0055 \%$. Accordingly, it is concluded that jackal bites and injuries are exceptionally low and that they pose no risk for patients who present routinely to the Zagreb Anti Rabies Clinic. Therefore, it is justified that jackal as an animal species be classified in the group of 'other animals', when officially reported.
\end{abstract}

Key words: Rabies - epidemiology; Rabies - statistics and numerical data; Croatia; Jackals - virology

\section{Introduction}

Rabies is a viral disease that occurs in more than 150 countries and territories worldwide. More than 55,000 people die from rabies every year, mostly in Africa and Asia. Once the symptoms of the disease have developed, rabies is always nearly fatal. Therefore, every year more than 15 million people worldwide receive the post-exposure rabies prophylaxis (PEP) to

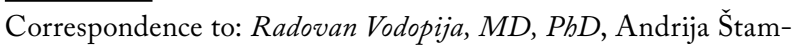
par Teaching Institute of Public Health, Mirogojska 16, HR10000 Zagreb, Croatia

E-mail: radovan.vodopija@stampar.hr

Received September 15, 2015, accepted November 19, 2015 prevent the disease. This number is estimated to prevent hundreds of thousands of rabies deaths annually.

People are usually infected following deep bite or scratch by an infected animal. Dogs are the main host and transmitter of rabies, and usually the source of infection in all estimated cases of human rabies deaths. Bats are the source of most human rabies deaths in the Americas. Bat rabies has also recently emerged as a public health threat in Australia and Western Europe. Human deaths following exposure to foxes, raccoons, skunks, jackals, mongooses and other wild carnivore host species are very rare ${ }^{1}$.

Jackal is the name of three species from the genus of dogs (Latin, Canis), small to medium size, whose 
habitat is in Africa, Asia and southeast Europe ${ }^{2}$. Jackals fill a similar 'ecologic hole' with coyotes (in the past known as 'American coyote) in North America. Both are omnivores, but they can hunt small to medium size animals and are known as vultures as well. Long legs and canine teeth are well adapted for hunting small mammals, birds and reptiles. Big feet and their leg bones enable them to run for long distances at a velocity of 16 miles/hour ( $25 \mathrm{kmh})$. They are most active at dawn and in the evening.

Jackals form monogamous pairs and defend their territory from other couples. They defend it aggressively and mark it with urine and feces. The territory can be big enough for the youngsters of that couple, which have not yet found their own territory. Sometimes, they come together in small groups to eat carcasses, but usually they hunt alone or in pairs.

Table 1. Prevalence of jackal bites and injuries at Zagreb Anti Rabies Clinic from 1995 to 2014

\begin{tabular}{|c|c|c|c|}
\hline Year & $\begin{array}{c}\text { Examined } \\
\text { patients }(\mathrm{n})\end{array}$ & $\begin{array}{c}\text { Treated patients } \\
(\text { PEP) }(\mathrm{n})\end{array}$ & Jackal (n) \\
\hline 1995 & 1380 & 187 & 0 \\
\hline 1996 & 1297 & 196 & 0 \\
\hline 1997 & 1196 & 207 & 0 \\
\hline 1998 & 1056 & 182 & 0 \\
\hline 1999 & 1129 & 196 & 0 \\
\hline 2000 & 1010 & 168 & 1 \\
\hline 2001 & 878 & 158 & 1 \\
\hline 2002 & 955 & 152 & 0 \\
\hline 2003 & 889 & 127 & 0 \\
\hline 2004 & 902 & 113 & 0 \\
\hline 2005 & 865 & 133 & 0 \\
\hline 2006 & 802 & 172 & 0 \\
\hline 2007 & 811 & 150 & 0 \\
\hline 2008 & 841 & 247 & 0 \\
\hline 2009 & 746 & 241 & 0 \\
\hline 2010 & 667 & 219 & 0 \\
\hline 2011 & 677 & 184 & 0 \\
\hline 2012 & 716 & 215 & 0 \\
\hline 2013 & 685 & 240 & 0 \\
\hline 2014 & 592 & 142 & 0 \\
\hline Total & 18094 & 3629 & 2 \\
\hline & & & \\
\hline
\end{tabular}

$\mathrm{PEP}=$ post-exposure rabies prophylaxis
The three types of jackals are: (a) side-striped jackal (Canis adustus) which, unlike other jackal species, primarily lives in forest areas. It is less aggressive and rarely feeds on bigger mammals. It can be found in central and southern Africa ${ }^{3}$; (b) golden jackal (Canis aureus), the biggest of all jackals, and the only species of jackals which can live outside Africa. Genetic studies have revealed it to be a very close kin of the gray wolf and coyote ${ }^{4,5}$. It can be found in North America, north Africa, southeast Europe, Middle East, and western and eastern Asia. There are 13 subspecies of the golden jackal ${ }^{6}$; and (c) black-backed jackal (Canis mesomelas), the smallest one and probably most aggressive of all jackal species, which can attack much bigger animals than itself. It can be found in South Africa, and eastern coasts of Kenya, Somalia end Ethiopia $^{7,8}$ (Figs. 1-3).

\section{Results}

During the 1995-2014 period, 18,094 persons were examined at the Zagreb Anti Rabies Clinic due to various animal bites and injuries, of which 3629 received PEP with anti rabies vaccine alone or in combination with human rabies immune globulin (HRIG). In the observed period, there were only two cases of jackal bites and injuries, one in 2000 and the other in 2001 (Table 1).

In the first case, the patient had been in contact with the saliva of a jackal against unbroken skin. The jackal was later proved to be rabid. It happened after checking up on his hunting dogs, which were full of saliva, and later on, the patient found that his hunting dogs had killed the jackal. The patient received PEP with anti rabies vaccine only.

In the second case, the patient was scratched by jackal teeth against clothes in France while hitchhiking. PEP was started in France, and after coming to Zagreb, the capital of Croatia, it was continued according to the prescribed schedule of vaccination.

\section{Discussion}

Apart from the two described jackal cases in the city of Zagreb, according to data from the Croatian Veterinary Institute in Zagreb, there were 12 registered cases of jackal rabies in Croatia during the study 
period. Five of them were reported from Zadar County, three from Dubrovnik-Neretva County, and one from Osijek-Baranja County, Šibenik-Knin County, Sisak-Moslavina County and Primorje-Gorski Kotar County each, all involving the type of golden jackal ${ }^{9}$.

Although dogs are the main host and transmitter of rabies, and usually the source of infection in all estimated cases of human rabies deaths, side-striped jackals (Canis mesomelas) are endemic species in Zimbabwe and they can spread rabies to domestic dogs ${ }^{10,11}$. There are at least four genetic variants of rabies virus (RABV) circulating in Africa ${ }^{12}$, of which two circulate in Zimbabwe and South Africa ${ }^{13}$. Besides dogs,
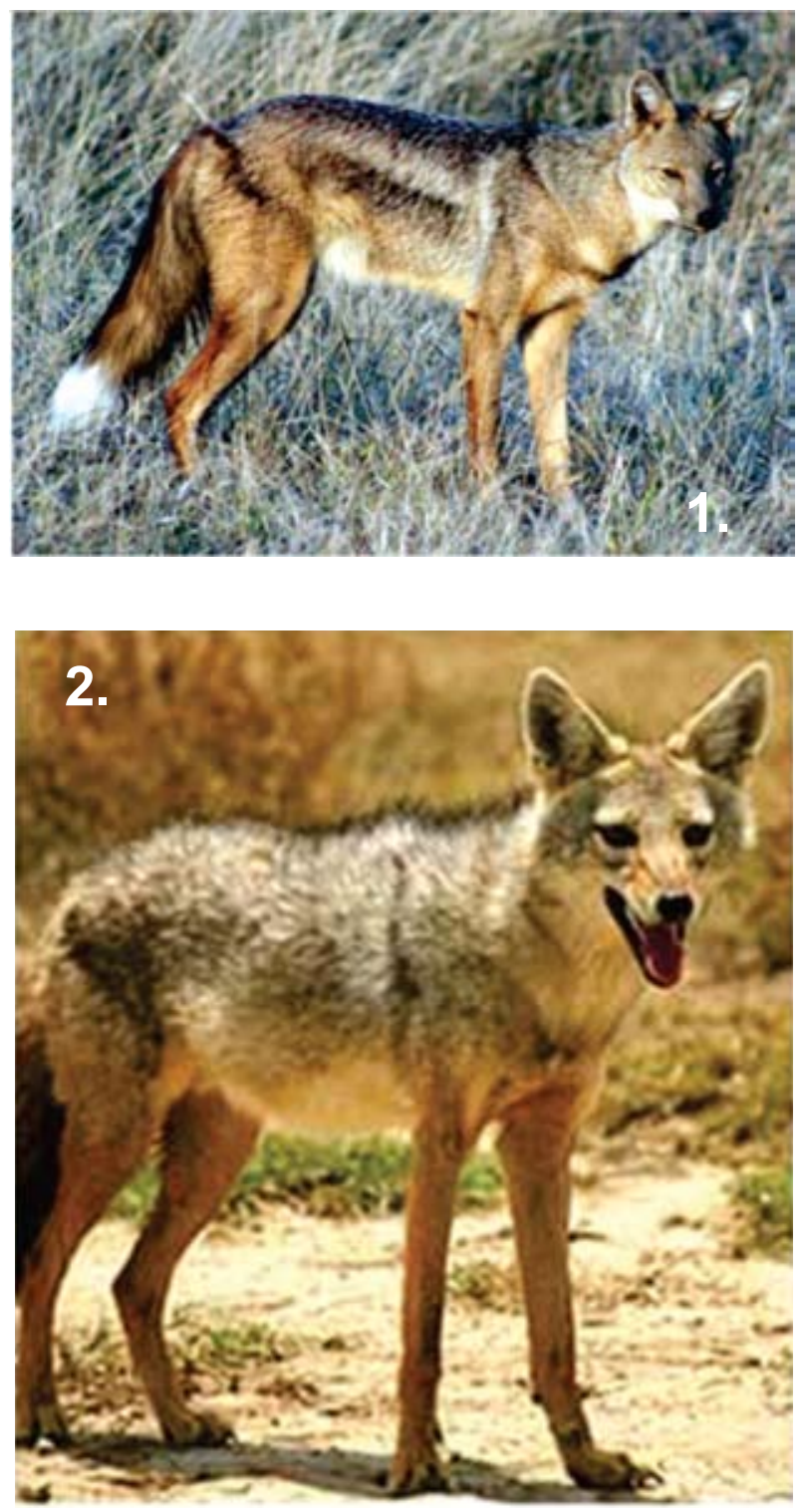

black-backed (Canis mesomelas) and side-striped (Canis adustus) jackals, bat-eared foxes and mongooses are included. Both canid and mongoose RABV reservoirs are maintained by their respective hosts, but there also are occasional spillovers into other species ${ }^{14,15}$. Pfukeny et al. in Zimbabwe showed connection between dogs and jackals (Canis adustus and Canis mesomelas) in over $90 \%$ of cases of rabies in humans ${ }^{16}$. Zulu et al. describe connection between domestic dogs and black-backed jackals from northern South Africa, stating that black-backed jackals (Canis mesomelas) are capable of sustaining rabies cycles independently of domestic dogs ${ }^{17}$. Munang'andu et al. describe rabies status in

Fig. 1. Side-striped jackal.

Available from: http:// retrieverman.files.wordpress. com/2012/05/side-stripedjackal.jpg

Fig. 2. Golden jackal.

Available from: http://www. ecoindia.com
Fig. 3. Black-backed jackal.

Available from: http:// www.google.hr/imgres? imgurl =http://www. theanimalfiles.com/images/black_backed_jackal_1. jpg\&imgrefurl=http://www. theanimalfiles.com/mammals/ carnivores/jackal_black backed.html\&h=195\&w=259 \&tbnid=zVkevPWgCFovHM :\&zoom=1\&tbnh=150\&tbnw= 200\&usg=_ffJcLcUJ5AGtzB yTOprIYGiwA $6 \times 0=\&$ docid $=$ Dr7O2v8h0pfs0M

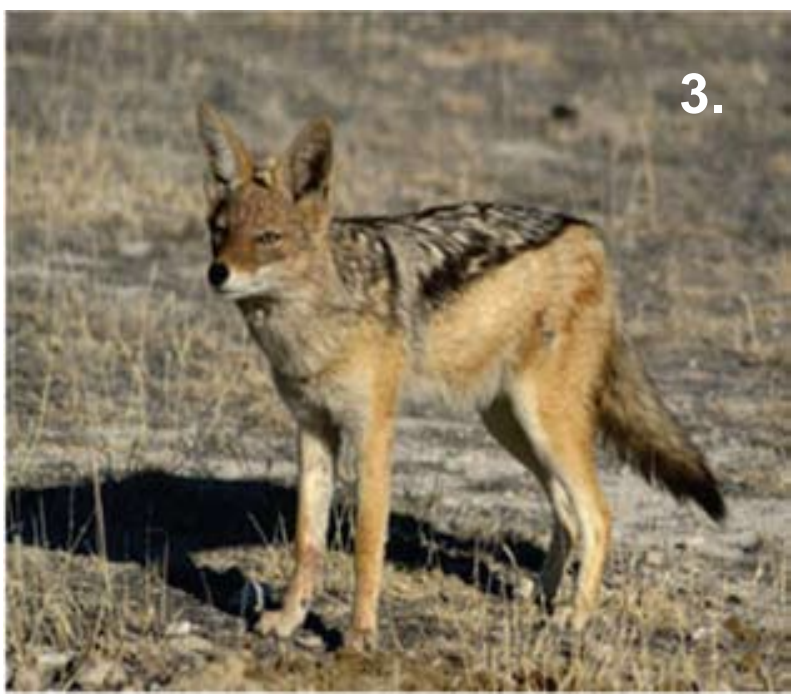


Zambia during the 1985-2004 period, estimating that side-striped jackal (Canis adustus) is the predominant animal species in wildlife tested for the presence of rabies virus, and that domestic dog is the main host of rabies ${ }^{18}$. Mac Donald et al. report that black-backed jackal (Canis mesomelas) is a species that is usually found across southern and eastern Africa ${ }^{19}$, while Bellan et al. using phylogenetic analysis estimate that in the Etosha National Park in Namibia, jackal RABV is part of the transmission cycle of dog-jackal RABV cycles in Namibia ${ }^{20}$. Prager et al. describe connection between RABV and canine distemper virus (CDV) in wild and domestic carnivores in northern Kenya; they report that the RABV risk for people and wild carnivores might be controlled by domestic dog vaccination, but CDV control would need to target the species of concern ${ }^{21}$. Rabies in wildlife with jackals included as animal species was recorded in Tanzania and Ethiopia ${ }^{22,23}$. Menezes describes rabies in India, where jackals are mentioned among other animals as animals that bite incidentally and therefore people seek $\mathrm{PEP}^{24}$.

Hammami et al. conducted a trial of oral vaccination of domestic and wild species, as well as rodents with SAG2 rabies virus mutant strain and demonstrated this oral vaccine to be effective in many target and non-target animal species ${ }^{25}$. Oral vaccination of red foxes was successfully conducted in Israel ${ }^{26}$, but despite oral vaccination, Israel is still at a risk of imported rabies cases from neighboring countries, and therefore has to carry out continuous monitoring along all of its borders ${ }^{27}$.

In conclusion, although persisting in Africa, Asia and some parts of Europe, rabies in jackals did not present major threat in the city of Zagreb in 19952014 period. Contacts with jackals are very rare and occur only in special occasions such as hunt or contact with domestic dogs. Direct attacks on humans are extremely rare. Considering the incidence of jackals as animal species appearing in the Zagreb Anti Rabies Clinic during the study period, they do not present any real concern for the patients at all. Therefore, it is justified to classify them into the category of 'other animals', when officially reported.

\section{References}

1. Rabies [Internet]. Geneva: WHO; 2015 [cited 2015 Aug 7]. Available from: http://www.who.int/mediacentre/factsheets/ fs099/en/

2. Čagljevi [Internet]. Florida: Wikipedia; 2015 [cited 2015 Aug 13]. Available from: https://hr.wikipedia.org/ wiki/\%C4\%8Cagljevi

3. Side-striped jackal [Internet]. Oxford: Canid Specialist Group; 2014 [cited 2015 Aug 15]. Available from: http:// www.canids.org/species/view/PREKMO428071

4. Golden jackal [Internet]. Oxford: Canid Specialist Group; 2014 [cited 2015 Aug 15]. Available from: http://www. canids.org/species/view/PREKMW872861

5. Lindblad-Toh K, Wade CM, Mikkelsen TS, Karlsson EK, Jaffe DB, Kamal M, et al. Genome sequence, comparative analysis nad haplotype structure of the domestic dog. Nature. 2005;438:803-19.

6. Wozencraft WC. Order Carnivora. In: Wilson DE, Reeder DM, editors. Mammal Species of the World. Baltimore: The Johns Hopkins University Press; 2005. p. 532-628.

7. MacDonald D. The Velvet Claw: A Natural History of the Carnivores. London: BBC Books; 1992.

8. Estes R. The Behaviour Guide to African Mammals: Including Hoofed Mammals, Carnivores, Primates. California: University of California Press; 1992.

9. Arhiva Hrvatskog veterinarskog instituta u Zagrebu od 1995. do 2013. godine. (in Croatian)

10. Cohen C, Sartorius B, Sabeta C, Zulu G, Paweska J, Mogoswane $\mathrm{M}$, et al. Epidemiology and molecular virus characterisation of reemerging rabies, South Africa. Emerg Infect Dis. 2007;13:1879-86.

11. Swanepoel R, Barnard BJ, Meredith CD, Bishop GC, Bruckner GK, Foggin CM, et al. Rabies in southern Africa. Onderstepoort J Vet Res. 1993;60:325-46.

12. Kissi B, Tordo N, Bourhy H. Genetic polymorphism in the rabies virus nucleoprotein gene. Virology. 1995;209:526-37.

13. Davis PL, Rambaut A, Bourhy H, Holmes EC. The evolutionary dynamics of canid and mongoose rabies virus in southern Africa. Arch Virol. 2007;152:1251-8.

14. Sabeta CT, Bingham J, Nel LH. Molecular epidemiology of canid rabies in Zimbabwe and South Africa. Virus Res. 2003;91:203-11.

15. Nel LH, Jacobs J, Jaftha J, Meredith C. Natural spillover of a distinctly Canidae-associated biotype of rabies virus into an expanded wildlife host range in southern Africa. Virus Genes. 1997;15:79-82.

16. Pfukenyi DM, Pawandiwa D, Makaya PV, Ushewokunze-Obatolu U. A retrospective study of rabies in humans in Zimbabwe, between 1992 and 2003. Acta Tropica. 2007;102:190-6.

17. Zulu GC, Sabeta CT, Nel LH. Molecular epidemiology of rabies: focus on domestic dogs (Canis familiaris) and black- 
backed jackals (Canis mesomelas) from northern South Africa. Virus Res. 2009;190:71-8.

18. Munang'andu HM, Mweene AS, Siamudaala V, Muma JB, Matandiko W. Rabies status in Zambia for the period 19852004. Zoonoses Public Health. 2011;58:21-7.

19. MacDonald DW, Loveridge AJ, Atkinson RPD. Jackals. In: MacDonald DW, Sillero-Zubiri C, editors. The Biology and Conservation of Wild Canids. Oxford, UK: Oxford University Press, 2004. p. 255-70.

20. Bellan SE, Cizauskas CA, Miyen J, Ebersohn K, Küsters M, Prager KC, et al. Black-backed jackal exposure to rabies virus, canine distemper virus, and Bacillus anthracis in Etosha $\mathrm{Na}-$ tional Park, Namibia. J Wild Dis. 2012;48:371-81.

21. Prager KC, Mazet JAK, Dubovi EJ, Frank LG, Munson L, Wagner AP, et al. Rabies virus and canine distemper virus in wild and domestic carnivores in northern Kenya: are domestic dogs the reservoir? EcoHealth. 2012;9:483-98.
22. Swai ES, Moshy WE, Kaaya JE, Mtui PF. Spatial and temporal distribution of rabies in northern Tanzania in the period of 2003-2002. Tanzan J Health Res. 2010;12:80-5.

23. Tefera G, Yimer E, Geyid A. Endemic existence of rabies in Ethiopia. Ethiop Med J. 2002;40:163-70.

24. Menezes R. Rabies in India. CMAJ. 2008;178:564-6. PubMed PMID: 18299543.

25. Hammami S, Schumacher CL, Cliquet F, Barrat J, Tlatli A, Osman $\mathrm{RB}$, et al. Safety evaluation of the SAG2 rabies virus mutant in Tunisian dogs and several non-target species. Vet Res. 1999;30:353-62.

26. Linhart SB, King R, Zamir S, Naveh U, Davidson M, Perl S. Oral rabies vaccination of red foxes and golden jackals in Israel: preliminary bait evaluation. Rev Sci Tech. 1997;16:87480.

27. David D, Yakobson BA. Review article: Dogs serve as a reservoir and transmit rabies in Israel. Is history repeating itself? Israel J Vet Med. 2011;66:3-8.

Sažetak

\section{UČESTALOST UGRIZA I OZLJEDA OD ČAGLJEVA U ANTIRABIČNOJ AMBULANTI U GRADU ZAGREBU OD 1995. DO 2014. GODINE}

\section{R. Vodopija, A. Racz i Đ. Pahor}

Bjesnoća je zoonoza (bolest koja se sa životinja prenosi na ljude) koja je uzrokovana virusom. Bolest zahvaća domaće i divlje životinje, a na ljude se širi putem bliskog kontakta sa zaraženim materijalima, obično slinom, putem ugriza ili ogrebotina. Bjesnoća je prisutna na svim kontinentima, s iznimkom Antarktike, budući da se više od $95 \%$ humanih slučajeva bjesnoće događa u Aziji i Africi. Jednom kada se razviju znaci bjesnoće ona je gotovo uvijek smrtonosna. Ljudi se obično zaraze putem ugriza ili ogrebotine zaražene životinje. Psi su glavni domaćin i prijenosnik bjesnoće. Izvorom su infekcije za gotovo 55.000 potvrđenih humanih slučajeva bjesnoće u Aziji i Africi. Šišmiši su izvor većine humanih slučajeva bjesnoće u obje Amerike. Bjesnoća u šišmiša također se nedavno pojavila u Australiji i u Zapadnoj Europi, gdje predstavlja rastuću javnozdravstvenu prijetnju. Zabilježeni humani slučajevi bjesnoće povezani s lisicama, rakunima, smrdljivcima, čagljevima, mungosima i ostalim divljim mesožderima su vrlo rijetki. U Zagrebačkoj antirabičnoj ambulanti, u razdoblju od 1995. do 2014. godine, pregledano je ukupno 18,094 pacijenata koje su ugrizle različite vrste životinja, ali se u samo 2 slučaja radilo o ugrizima čagljeva. Prvi je bio uvezen iz Francuske, a drugi iz Republike Hrvatske. Učestalost ugriza i ozljeda zadanih od čagljeva u promatranom razdoblju bila je iznimno niska i činila je $0,011 \%$ od svih životinjskih vrsta. Kada se isključi uvezeni slučaj, učestalost iznosi $0,0055 \%$. Prema tome, može se zaključiti da su ugrizi i ozljede od čagljeva iznimno rijetki po učestalosti pojavljivanja te da ne predstavljaju rizik za pacijente koji rutinski dolaze u antirabičnu ambulantu u gradu Zagrebu na pregled. Zbog toga je opravdano da se čagalj kao životinjska vrsta kategorizira u skupinu "ostalih životinja", kada se službeno prikazuje u izvješćima.

Ključne riječi: Bjesnoća - epidemiologija; Bjesnoća - statistika i brojčani podaci; Hrvatska; Čagljevi - virologija 